\title{
Effect of feeding different mulberry varieties on some biological characteristics of the silkworm, Bombyx mori $\mathrm{L}$.
}

\author{
Atef A. El-Banna ${ }^{* 1}$, Marwa N. Moustafa ${ }^{2}$, Souad M. Mahmoud ${ }^{2}$, Akila M. El-Shafei ${ }^{1}$ and Amr A. \\ Moustafa $^{3}$ \\ ${ }^{l}$ Department of Entomology, Faculty of Science, Ain Shams University, Cairo, Egypt, \\ ${ }^{2}$ Sericulture Research Department, Plant Protection Research Institute - Agricultural Research Center, Cairo, Egypt, \\ ${ }^{3}$ Department of Biochemistry, Faculty of Agriculture, Cairo University, Cairo, Egypt.
}

A R T I C L E I N F O

Article history:

Received 24 October 2013

Accepted 21 November 2013

Keywords:

Silkworm;

Bombyx mori L.;

mulberry.

\begin{abstract}
A B S T R A C T
The biological effects of feeding the silkworm Bombyx mori L. on six varieties of mulberry (Morus alba var. Kokuso-27, Sh2xLunlog, Kaeryang-ppong, Kanava-2, Leavigata, and Morus nigra var. Arandaly) were studied. Results revealed significant differences in duration, weight and growth rate of the larvae. There was also a noticeable difference in effective rate of rearing, approximate digestibility, and efficiency of conversion of ingested and digested food to body substance.

It could be generally concluded that Kokuso-27 and Sh2xlunlog improved the growth rate value compared to the four other mulberry varieties.
\end{abstract}

\section{Introduction}

The silkworm Bombyx mori L. (Order: Lepidoptera, Family: Bombycidae) is a highly specialized monophagous insect feeding on Morus leaves. Morus, commonly known as mulberry, belongs to the family Moraceae. It is cultivated for its yield since its leaves are the only food source for the silkworm. Nearly 70 percent of the silk proteins produced by silkworm are directly derived from the proteins of mulberry leaves ${ }^{[1]}$. The variable growth rate of organs of the silkworm is clearly reflected during development and differentiation. Differential growth varies depending upon the genetic endowment of the race apart from the quality and quantity of food intake and climatic conditions ${ }^{[2]}$.

The nutritive effects of the leaves of the different mulberry varieties on larval growth and cocoon characters, are reflected on cocoon yield and thus on silk production. Qader et al., ${ }^{[3]}$ found that the mature larval weight, single cocoon weight, shell weight, shell percentage and filament length were greatly influenced by the nutritive value of different mulberry leaves.

Some of the Morus plants are rich sources of natural phenolic compounds including flavonoids. Such phenolic compounds are indispensable components of the synthetic diet for Bombyx mori L. and enhance the rate of development in the early stage ${ }^{[4]}$.

* Corresponding author.

E-mail address: aebdirect@hotmail.com

\section{Materials and Methods}

\section{I- Silkworm rearing:}

Silkworm eggs of the monovoltine race (S.A.105) were obtained from the Sericulture Research Department (SRD) of the Plant Protection Research Institute (PPRI) and reared at the same department from hatching till cocoon formation according to the standard method of rearing in SRD.

Eggs were incubated in an incubator adjusted at $25^{\circ} \mathrm{C}$ and $75 \%$ relative humidity. Hatched larvae were transferred from the egg cards to the rearing trays. Rearing was carried out during two successive spring seasons of 2010 and 2011 under laboratory conditions $\left(28 \pm 2{ }^{\circ} \mathrm{C}\right.$ and $\left.75 \pm 5 \% \mathrm{RH}\right)$. Removal of fecal matter, diseased larvae and bed cleaning were done at regular intervals.

Larvae were divided into six groups. Each group was fed four times a day on one of the following fresh mulberry varieties:

Morus alba var. Kokuso-27 imported from Japan. Morus alba var. Leavigata imported from Pakistan.

Morus alba var .Kanava-2 imported from India.

Morus alba var. Kaeryang-ppong imported from North Korea.

Morus alba var. Sh2xLunlog imported from China. Morus nigra var. Arandaly (native) 


\section{II- Biological Studies on the larvae of the silkworm:} II-1- Larval duration:

Larval duration was observed from day of hatching till day of spinning and recorded in days.

\section{II-2- Weight of larvae:}

At the end of $3^{\text {rd }}, 4^{\text {th }}$ and $5^{\text {th }}$ instars, 30 larvae from each treatment were weighed separately, and the average weight was calculated.

\section{II-3- Growth rate:}

This is measured as the gain in weight over the initial weight at the $4^{\text {th }}$ and $5^{\text {th }}$ instars and calculated according to Waldbauer ${ }^{[5]}$.

Growth rate $=(\mathrm{A} / \mathrm{BxC})$

$\mathrm{A}=$ Weight gain during larval period (g.)

$\mathrm{B}=$ Duration of larval period (days)

$\mathrm{C}=$ Mean weight of larval during the same period (g.)

\section{II-4- Effective Rate of Rearing (ERR\%):}

Eggs of each card were counted before hatching, then larvae were counted after the third molt for estimating the ERR\%. At the beginning of the $4^{\text {th }}$ larval instar, 300 larvae separated from mass rearing were used for estimating ERR\% for the grown larvae. The percentage of young instars and also the $4^{\text {th }}$ and $5^{\text {th }}$ instars were calculated according to the following formula:

Percentage of mortality $=$ No. of live larvae $\times 100$

$$
\text { Total No. of larvae }
$$

\section{II-5- Food utilization:}

The amount of consumed food, ingested, digested and converted into dry matter and all the indices studied, were determined using the standard gravimetric methods of Waldbaur ${ }^{[5]}$.

\section{II-5-1- Weight of food consumption:}

Estimation of the mean weight of fresh food consumed by $5^{\text {th }}$ instar larvae of the different varieties of mulberry leaves was determined as follows:

Blank $=\underline{\text { Total weight of fresh leaves fed to the larvae during an instar }}$

Weight of dry leaves in the control tray at the end of the same instar Weight of fresh remnant $=$ Weight of dry remnant X Blank

II-5-2- Approximate weight of food digested (AD) $(\mathrm{AD})=$ Weight of consumed food - Weight of fresh remnant.

II-5-3- Approximate digestibility (AD\%)

$(\mathrm{AD} \%)=\underline{\text { Approximate weight of food digested }} \times 100$ Weight of consumed food

II-5-4- Efficiency of conversion of food ingested to body substances (ECI)

$(\mathrm{ECI})=\underline{\text { Increase in weight of larvae }}$ X 100 Weight of consumed food

II-5-5- Efficiency of conversion of food digested to body matter (ECD)

$(E C D)=$ Increase in weight of larvae $\quad$ X 100

Approximate weight of food digested

\section{Results and discussion}

1- Effect of feeding mulberry varieties on the larval stage of the silkworm:

Studies were carried out on the SA105 silkworm race fed on six mulberry varieties. The rearing data pertaining to the biological characteristics are detailed in (Table1).

\section{II-1- Larval duration:}

Larval duration from hatching of eggs till spinning the cocoons was estimated as an important parameter since increased larval duration has an influence on rearing performance, cocoon and grainage parameters. The obtained results reveal that the six mulberry varieties had a noticeable effect on larval duration of the young instars and recorded (18 days) for both of Kokuso-27, Sh2xlunlog and Arandaly, while Kearyang-ppong and Kanava-2 recorded (19 days). Larval duration was prolonged in larvae feeding on Leavigata (20 days).

During the $4^{\text {th }}$ larval instar, larvae fed on the different mulberry varieties all recorded (6 days) except Leavigata which recorded the longest duration of 7 days.

During the $5^{\text {th }}$ instar, the two mulberry varieties Kokuso-27 and Sh2xlunlog recorded the shortest larval duration (8 days), Arandaly, Kearyang-ppong and Kanava-2 (9 days), while Leavigata registered the longest duration of 10 days.

The total larval duration followed the same trend and recorded 32, 32, 33, 34, 34 and 37 days in case of Kokuso-27, Sh2xlunlog, Arandaly, Kearyang-ppong, Kanava-2 and Leavigata, respectively. Zannoon et al. ${ }^{[\mathbf{6}]}$ found that rearing with Kokuso-27 leaves exhibited a significantly shorter larval duration when compared to Morus indica var. Kanva-2 and Morus alba var. Balady (native). Mendonca et al. ${ }^{[7]}$ similarly found that feeding on different mulberry hybrids affected the duration of the larval period and weight of caterpillars, prepupae and silk glands.

\section{II-2- Weight of larvae:}

Weight of young, $4^{\text {th }}$ and $5^{\text {th }}$ instars differed significantly between the mulberry varieties (Table 1).

Weight of young larvae at the end of $3^{\text {rd }}$ instar registered $0.160,0.155,0.133,0.128,0.124$ and $0.119 \mathrm{~g}$ for Kokuso-27, Sh2xlunlog, Arandaly, Kearyangppong, Kanava-2 and Leavigata, respectively.

The mean weight of $4^{\text {th }}$ larval instar fed on Kokuso-27 $(0.728 \mathrm{~g})$ was found to be significantly higher than the other mulberry varieties followed by Sh2xlunlog (0.663 g), Arandaly (0.584 g), Kearyang-ppong (0.540 g), kanava-2 (0.494 g) and Leavigata $(0.425 \mathrm{~g})$.

Weight of the $5^{\text {th }}$ instar larvae fed on the same above mulberry varieties recorded $3.064 \mathrm{~g}, \mathbf{2 . 9 1 2 g}, 2.730 \mathrm{~g}$, $2.640 \mathrm{~g}, 2.402 \mathrm{~g}$ and $1.732 \mathrm{~g}$, respectively. However, no significant difference was noticed between Arandaly and Kearyang-ppong. Karimullah et al. ${ }^{[8]}$ found that weights of 11-day-old larvae varied significantly among the tested cultivars. Qader et al., ${ }^{[3]}$ concluded that mature larval weight and cocoon weight were greatly influenced by the nutritive value of the different mulberry leaves. Porto and Okamoto [9] observed a difference in performance in terms of live weight and weight gain of $B$. mori L. larvae when fed on different mulberry cultivars. 
Table 1: Effect of feeding with six mulberry varieties on some biological characteristics of the silkworm, Bombyx mori $\mathrm{L}$.

\begin{tabular}{|c|c|c|c|c|c|c|c|}
\hline 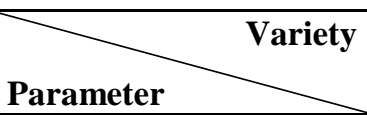 & Kokuso-27 & Sh2xlunlog & Arandaly & $\begin{array}{l}\text { Kearyang- } \\
\text { ppong }\end{array}$ & Kanava-2 & Leavigata & L.SD \\
\hline $\begin{array}{c}\text { Young instar duration } \\
\text { (days) }\end{array}$ & 18 & 18 & 18 & 19 & 19 & 20 & -- \\
\hline $\begin{array}{c}4^{\text {th }} \text { duration } \\
\text { (days) }\end{array}$ & 6 & 6 & 6 & 6 & 6 & 7 & -- \\
\hline $\begin{array}{l}5^{\text {th }} \text { duration } \\
\text { (days) }\end{array}$ & 8 & 8 & 9 & 9 & 9 & 10 & -- \\
\hline $\begin{array}{c}\text { Total larval period } \\
\text { (days) }\end{array}$ & 32 & 32 & 33 & 34 & 34 & 37 & - \\
\hline $3^{\text {rd }}$ larval weight & $\begin{array}{c}\mathrm{a} \\
0.160\end{array}$ & $\begin{array}{c}\mathrm{a} \\
0.155\end{array}$ & $\begin{array}{c}\mathrm{b} \\
0.133 \\
\end{array}$ & $\begin{array}{c}\mathrm{bc} \\
0.128\end{array}$ & $\begin{array}{c}\mathrm{cd} \\
0.124\end{array}$ & $\begin{array}{c}\mathrm{d} \\
0.119\end{array}$ & 0.005 \\
\hline $4^{\text {th }}$ larval weight & $\begin{array}{c}\mathrm{a} \\
0.728\end{array}$ & $\begin{array}{c}\mathrm{b} \\
0.663\end{array}$ & $\begin{array}{c}\mathrm{c} \\
0.584\end{array}$ & $\begin{array}{c}\mathrm{d} \\
0.540\end{array}$ & $\begin{array}{c}\mathrm{e} \\
0.494\end{array}$ & $\begin{array}{c}f \\
0.425\end{array}$ & 0.016 \\
\hline $5^{\text {th }}$ larval weight & $\begin{array}{c}\mathrm{a} \\
3.064 \\
\end{array}$ & $\begin{array}{c}\mathrm{b} \\
2.912\end{array}$ & $\begin{array}{c}\mathrm{c} \\
2.731 \\
\end{array}$ & $\begin{array}{c}c \\
2.640\end{array}$ & $\begin{array}{c}\mathrm{d} \\
2.402\end{array}$ & $\begin{array}{c}\mathrm{e} \\
1.732 \\
\end{array}$ & 0.093 \\
\hline $4^{\text {th }}$ growth rate & $\begin{array}{c}\mathrm{a} \\
0.129 \\
\end{array}$ & $\begin{array}{c}\mathrm{ba} \\
0.126 \\
\end{array}$ & $\begin{array}{c}\text { ba } \\
0.127\end{array}$ & $\begin{array}{c}\mathrm{ba} \\
0.126 \\
\end{array}$ & $\begin{array}{c}\mathrm{b} \\
0.124 \\
\end{array}$ & $\begin{array}{c}\mathrm{c} \\
0.102 \\
\end{array}$ & 0.004 \\
\hline $5^{\text {th }}$ growth rate & $\begin{array}{c}\mathrm{a} \\
0.096\end{array}$ & $\begin{array}{c}\mathrm{a} \\
0.096\end{array}$ & $\begin{array}{c}\mathrm{b} \\
0.087\end{array}$ & $\begin{array}{c}\mathrm{b} \\
0.088\end{array}$ & $\begin{array}{c}\mathrm{b} \\
0.087\end{array}$ & $\begin{array}{c}\mathrm{c} \\
0.073\end{array}$ & 0.004 \\
\hline
\end{tabular}

Similarly, Sujatha et al. ${ }^{[10]}$ found that rearing of the bivoltine breed, PM x NB4D2, with six mulberry varieties, resulted in a difference in weight of $4^{\text {th }}$ instar larvae and mature larvae and cocoon and post-cocoon parameters.

\section{II-3- Growth rate:}

When considering these results in the form of "growth rate" by relating the weight of larvae at the end of the previous instar. It was found that the weight gained was highest in larvae fed on Kokuso-27 and Sh2xlunlog and superior than the other varieties. Arandaly and Kearyang-ppong were the same and ranked next to the first two varieties, while Leavigata was the least during the $4^{\text {th }}$ instar.

The following values of $0.129,0.126,0.127,0.126$, 0.124 and 0.102 are growth rate values for $4^{\text {th }}$ instar larvae, and 0.096, 0.096, 0.087, 0.088, 0.087 and 0.073 for $5^{\text {th }}$ instar larvae fed on Kokuso-27, Sh2xlunlog, Arandaly, Kearyang-ppong, Kanava-2 and Leavigata, respectively.

It could be concluded that Kokuso-27 and Sh2xlunlog improved the growth rate value compared to the four other mulberry varieties. Lakshmipathi et al. ${ }^{[11]}$ in evaluating the growth rate of silkworms obtained an overall growth rate per day of 0.22 in all the categories.

\section{II-4- Effective Rate of Rearing (ERR):}

Table (2) shows that the highest mean of ERR was observed in B. mori L. fed on Kokuso-27, Sh2xlunlog and Arandaly during the young instars, $4^{\text {th }}$ and $5^{\text {th }}$ larval instars (100\%). kearyang-ppong recorded (99.80, 100 and $100 \%)$. Larvae fed on Leavigata recorded (99.50, 98.45 and $97.40 \%$ ), respectively. Venkatesh et al ${ }^{[\mathbf{1 2}]}$ showed that both cocoon weight and survival influence the productive traits such as fecundity, larval weight and effective rate of rearing of the next generation.

II-5- Utilization of the six mulberry varieties by the silkworm, B. mori L.:

The feeding process in $B$. mori L. as influenced by the different mulberry varieties, comprises the rate of food consumed, digestibility and conversion of food to body substance.

\section{II-5-1- Weight of food consumption:}

As shown in (Table 3), the quantity of food consumed differs between the mulberry varieties. Maximum mean consumption was recorded in case of Kokuso-27 fed to larvae during $4^{\text {th }}$ larval instar (2.343g) followed by Sh2xlunlog (2.179g), Arandaly (1.996g), Kearyangppong (1.896g), Kanava-2 (1.765g) and Leavigata (1.665g).

During the $5^{\text {th }}$ larval instar, the same trend was observed where maximum mean consumption was recorded for Kokuso-27. The values were $(12.980 \mathrm{~g}, 12.792 \mathrm{~g}$, $12.589 \mathrm{~g}, 12.381 \mathrm{~g}, 12.224 \mathrm{~g}$ and $11.974 \mathrm{~g}$ ) for the same arrangement of above mulberry varieties, respectively (Table 4). However, Sabhat et al. ${ }^{[13]}$ obtained maximum results when using Goshoerami variety rather than Kokuso-20 variety.

\section{II-5-2- Approximate weight of food digested (A.D):}

The quantity of food utilized during $4^{\text {th }}$ and $5^{\text {th }}$ instar expressed in terms of approximate weights of food digested (A.D) (Tables 3 \& 4) differed significantly between the six mulberry varieties. The highest weight of utilization was obtained in Leavigata $(0.925 \mathrm{~g})$ followed by Kanava-2 and Kearyang-ppong $(0.794 \mathrm{~g}$ and $0.766 \mathrm{~g})$, respectively, during $4^{\text {th }}$ larval instar and $(5.008 \mathrm{~g}, 4.291 \mathrm{~g}$ and $3.749 \mathrm{~g}$ ) during $5^{\text {th }}$ larval instar. The three other varieties; Kokuso-27, Sh2xlunlog and Arandaly, registered lower (A.D) and recorded $(0.666 \mathrm{~g}, 0.668 \mathrm{~g}$ and 
Table 2: Effect of feeding with six mulberry varieties on the effective rate of rearing of the silkworm, Bombyx mori L.

\begin{tabular}{|c|c|c|c|c|c|c|c|c|}
\hline \multicolumn{2}{|c|}{ Parameter } & Kokuso-27 & Sh $_{2}$ xlunlog & Arandaly & $\begin{array}{c}\text { Kearyang- } \\
\text { ppong }\end{array}$ & Kanava-2 & Leavigata & L.S.D \\
\hline \multirow{3}{*}{$\begin{array}{l}\Delta^{\circ} \\
\simeq \\
\simeq \\
\simeq\end{array}$} & $\begin{array}{l}\text { Young } \\
\text { instar }\end{array}$ & 100 & 100 & 100 & 99.8 & 99.75 & 99.5 & - \\
\hline & $\begin{array}{c}4^{\text {th }} \\
\text { instar }\end{array}$ & 100 & 100 & 100 & 100 & 100 & 98.45 & - \\
\hline & $\begin{array}{c}5^{\text {th }} \\
\text { instar }\end{array}$ & 100 & 100 & 100 & 100 & 99.44 & 97.4 & - \\
\hline
\end{tabular}

Table 3: Consumption efficiency of $4^{\text {th }}$ instar larvae fed on six mulberry varieties.

\begin{tabular}{|c|c|c|c|c|c|c|c|}
\hline Parameters & Kokuso-27 & Sh2xlunlog & Arandaly & $\begin{array}{c}\text { Kearyang- } \\
\text { ppong }\end{array}$ & Kanava-2 & Leavigata & L.S.D \\
\hline Consumed food & $\begin{array}{c}\mathrm{a} \\
2.343\end{array}$ & $\begin{array}{c}\mathrm{b} \\
2.179\end{array}$ & $\begin{array}{c}c \\
1.996\end{array}$ & $\begin{array}{c}\mathrm{d} \\
1.896\end{array}$ & $\begin{array}{c}\mathrm{e} \\
1.765\end{array}$ & $\begin{array}{c}\mathrm{f} \\
1.665\end{array}$ & 0.017 \\
\hline AD & $\begin{array}{c}d \\
0.668\end{array}$ & $\begin{array}{c}d \\
0.668\end{array}$ & $\begin{array}{c}c \\
0.756\end{array}$ & $\begin{array}{c}c \\
0.766\end{array}$ & $\begin{array}{c}\mathrm{b} \\
0.794\end{array}$ & $\begin{array}{c}\mathrm{a} \\
0.925\end{array}$ & 0.021 \\
\hline AD \% & $\begin{array}{c}\mathrm{f} \\
28.356\end{array}$ & $\begin{array}{c}\mathrm{e} \\
30.693\end{array}$ & $\begin{array}{c}\mathrm{d} \\
37.906\end{array}$ & $\begin{array}{c}c \\
40.383\end{array}$ & $\begin{array}{c}\mathrm{b} \\
45.030\end{array}$ & $\stackrel{\mathrm{a}}{55.566}$ & 1.017 \\
\hline ECI\% & $\begin{array}{c}\mathrm{a} \\
23.943\end{array}$ & $\begin{array}{c}\mathrm{b} \\
23.430\end{array}$ & $\begin{array}{c}\mathrm{c} \\
21.513\end{array}$ & $\begin{array}{c}\mathrm{d} \\
20.826\end{array}$ & $\begin{array}{c}\mathrm{e} \\
20.240\end{array}$ & $\begin{array}{c}\mathrm{f} \\
18.033\end{array}$ & 0.312 \\
\hline ECD\% & $\frac{a}{84.443}$ & $\begin{array}{c}\mathrm{b} \\
76.443\end{array}$ & $\begin{array}{c}c \\
56.763\end{array}$ & $\begin{array}{c}\mathrm{d} \\
51.600\end{array}$ & $\begin{array}{c}\mathrm{e} \\
45.013\end{array}$ & $\begin{array}{c}\mathrm{f} \\
32.460\end{array}$ & 3.099 \\
\hline
\end{tabular}

Table 4: Consumption efficiency of $5^{\text {th }}$ instar larvae fed on six mulberry varieties.

\begin{tabular}{|c|c|c|c|c|c|c|c|}
\hline Parameters & Kokuso-27 & Sh2xlunlog & Arandaly & $\begin{array}{c}\text { Kearyang- } \\
\text { ppong }\end{array}$ & Kanava-2 & Leavigata & L.S.D \\
\hline Consumed food & $\begin{array}{c}\mathrm{a} \\
12.980\end{array}$ & $\begin{array}{c}\text { ba } \\
12.792\end{array}$ & $\begin{array}{c}\mathrm{b} \\
12.589\end{array}$ & $\begin{array}{c}c \\
12.381\end{array}$ & $\begin{array}{c}\mathrm{c} \\
12.224\end{array}$ & $\frac{d}{11.974}$ & 0.206 \\
\hline AD & $\begin{array}{c}\mathrm{d} \\
2.982\end{array}$ & $\begin{array}{c}\mathrm{d} \\
2.999\end{array}$ & $\begin{array}{c}\mathrm{d} \\
3.235\end{array}$ & $\begin{array}{c}c \\
3.749\end{array}$ & $\begin{array}{c}\mathrm{b} \\
4.291\end{array}$ & $\begin{array}{c}\mathrm{a} \\
5.008\end{array}$ & 0.409 \\
\hline AD\% & $\begin{array}{c}\mathrm{d} \\
22.966\end{array}$ & $\frac{d}{23.423}$ & $\begin{array}{c}\mathrm{d} \\
25.682\end{array}$ & $\begin{array}{c}\mathrm{c} \\
30.278\end{array}$ & $\begin{array}{c}\mathrm{b} \\
35.088\end{array}$ & $\begin{array}{c}\mathrm{a} \\
41843\end{array}$ & 3.249 \\
\hline ECI\% & $\frac{\mathrm{a}}{18.023}$ & $\begin{array}{c}\text { ba } \\
17.556\end{array}$ & $\begin{array}{c}\mathrm{b} \\
17.126\end{array}$ & $\begin{array}{c}\mathrm{b} \\
16.788\end{array}$ & $\begin{array}{c}\mathrm{c} \\
15.698\end{array}$ & $\frac{d}{11.723}$ & 0.802 \\
\hline ECD\% & $\begin{array}{c}\mathrm{a} \\
78.336\end{array}$ & $\begin{array}{c}\mathrm{a} \\
75.217\end{array}$ & $\begin{array}{c}b \\
66.336\end{array}$ & $\begin{array}{c}c \\
56.01\end{array}$ & $\underset{46.46}{d}$ & $\begin{array}{c}\mathrm{e} \\
26.098\end{array}$ & 5.029 \\
\hline
\end{tabular}

$\mathrm{AD}=$ Approximate Digest. $\mathrm{AD}(\%)=$ Approximate Digestibility Percent.

$\mathrm{ECI} \%=$ Efficiency of conversion of ingested food to body substances.

$\mathrm{ECD} \%=$ Efficiency of conversion of food digested to body matter.

- Each mean out of 3 replicates.

- Means followed by the same letter in the same row are not significantly different $(\mathrm{P}>0.01)$. 
$0.756 \mathrm{~g})$ and $(2.982 \mathrm{~g}, 2.999 \mathrm{~g}$ and $3.235 \mathrm{~g})$ during $4^{\text {th }}$ and $5^{\text {th }}$ larval instars, respectively. In similar studies, Kumar and Kumar ${ }^{[14]}$ also found a difference in amounts of food ingested and in digestibility when feeding silkworms on different varieties of mulberry leaves.

\section{II-5-3- Approximate Digestibility (A.D\%):}

The approximate digestibility (A.D\%) was computed for all the mulberry varieties during the $4^{\text {th }}$ and $5^{\text {th }}$ larval instars and the highest percentage was shown in Leavigata $(55.56 \%)$ followed by Kanava-2 (45.03\%), Kearyang-ppong (40.383\%), and Arandaly (37.906\%), while the least (A.D\%) was shown in Sh2xlunlog $(30.693 \%)$ and Kokuso-27 $(28.356 \%)$ during the $4^{\text {th }}$ larval instar (Table 3).

The same trend was noticed during $5^{\text {th }}$ larval instar where the (A.D.\%) recorded 41.834, 35.088, 30.278, $25.681,23.423$ and $22.966 \%$ with Leavigata, Kanava-2, Kearyang-ppong, Arandaly, Sh2xlunlog and Kokuso-27, respectively (Table 4). In general, digestibility is an important factor to be put in consideration when rearing the silkworm for silk production. Furthermore, digestibility is affected by nutritional deficiency or imbalanced diet, high content of crude fiber or deficiency of water in food ${ }^{[15]}$.

II-5-4- Efficiency of conversion of food ingested to body substance (E.C.I\%):

The efficiency of conversion of ingested dry matter to body substance is an overall indicator of the insect ability to utilize ingested food for growth ${ }^{[16]}$

The E.C.I\% differed in case of the various mulberry varieties, increasing from 18.033 to $23.943 \%$ as shown in Tables (3\&4). The E.C.I\% varied significantly and was found to be maximum in Kokuso-27 23.943\%, Sh2xlunlog (23.43\%), Arandaly (21.513\%), Kearyangppong (20.826\%), Kanava-2 (20.24\%) and Leavigata $(18.033 \%)$. (Table 3$)$. During the $5^{\text {th }}$ instar, E.C.I values were $(17.996 \%)$ for Kokuso-27, (17.58\%) for Sh2xlunlog, (17.046\%) for Arandaly, (16.961\%) for Kearyang-ppong, (15.608) for Kanava-2 and (10.915\%) for Leavigata. (Table 4).

II-5-5- Efficiency of conversion of digested food to body substance (E.C.D\%):

The efficiency of conversion of digested food into body matter (E.C.D\%) varied significantly among the different mulberry varieties fed to the silkworm. The highest efficiency of conversion $\mathbf{( 8 4 . 4 4 \%}$ ) was obtained when larvae were fed on Kokuso-27 while the lowest was found in larvae fed on Leavigata $\mathbf{( 3 2 . 4 6 \% )}$. In case of Sh2xlunlog, Arandaly, Kearyang-ppong and Kanava2 , these values were $(76.443 \%, 56.763 \%, 51.6 \%$ and $45.013 \%)$, respectively, during the $4^{\text {th }}$ larval instar (Table 3).

During the $5^{\text {th }}$ larval instar, (E.C.D) values followed the same trend of the $4^{\text {th }}$ instar. However, there was no significance between Kokuso-27 and Sh2xlunlog recording (78.336, 75.217, 66.336, 56.01, 44.46 and $26.098 \%$ ) for Kokuso-27, Sh2xlunlog, Arandaly,
Kearyang-ppong, Kanava-2 and Leavigata, respectively (Table 4).

Generally, the conversion of ingested food and digested food into body matter was lowest in Leavigata variety. Sabhat et al. ${ }^{[13]}$ evaluated the effect of three different mulberry varieties (Ichinose, Kokuso-20 and Goshoerami) on three silkworm breeds. They found that there was a difference in nutritional parameters such as, efficiency of conversion of ingested food and digested food into body matter, leaf ingested, leaf digested, approximate digestibility, growth rate, consumption index and coefficient of metabolism.

\section{References}

1) Bari, M.A., Islam, R. and Salam, M.A. (1985). Feeding effect of 3- mulberry varieties on Nistari race of silkworm (Bombyx mori L.). Bangladesh J. Zool., 13(1): 13-18.

2) Maribashetty, V.G. and Reddy, G.S. (1998). Activity of 3- phosphoglycerate dehydrogenase in certain races of the silkworm, Bombyx mori L. Indian J. Seric. .37(2): 180-182.

3) Qader, M.A., Haque, R., Absar, N. (1992). Nutritive effects of different types of mulberry leaves on larval growth and cocoon characters of Bombyx mori L. Pak. J. Zool. 24(4): 341-345.

4) Germanò, M.P., D'Angelo, V., Catania, S., Miano, T.C., Perna, V., Faragò, S., Cappellozza, L., and Cappellozza, S. (2008). Phenolic content of leaves of different mulberry cultivars affect growth in the silkworm. Proc. of XXI Int. Seric. Comm. (ISC) Congr. Athens. 25-29.

5) Waldbauer, G.P. (1968). The consumption and utilization of food by insects. Adv. Insect physiol., 5:229-282.

6) Zannoon, A., Hassan, Eman M.M., El-Akkad, S.S., Abdel-Nabi, I.M., and Zalat, S.M. (2008). Biological and technological effects of mulberry varieties and nutritional additives on silkworm Bombyx mori development. Egyptian Journal of Biology, (10): 1-10.

7) Mendonca, G.A., de Marchini, L.C. and Macedo, L.P.M. (2010). Cocoon production of the silkworm, Bombyx mori L. (Lepidoptera: Bombycidae), fed on leaves of mulberry hybrids, Caatinga, 23(3): 118122.

8) Karimullah, Q.J., Ahmad, M.I., Hafiz, I.A., Ashiq, M.N. and Shah, M.F. (1989). Effect of some varieties of mulberry on the development of Bombyx mori L. and cocoon quality. Sarhad Journal of Agriculture, 5(5): 489-492.

9) Porto, A.J. and Okamoto, F. (2000). Utilization systems of two mulberry cultivars in two phases of vegetative development in the silkworm (Bombyx mori L.) performance. Boletim de Industria Animal, 57(2): 171-178.

10) Sujatha, P., Prasad, P.R. and Rao, N.V. (2000). Influence of different mulberry varieties on larval, 
cocoon and post-cocoon parameters of Bombyx mori L. Pest Management and Economic Zoology, 8(2): 161-165.

11) Lakshmipathi,

T.H.,

Krishnappa, Narayanaswamy, T.K., Gangappa, E. (2005). Establishing a relation between shape index on larval and silk traits of silkworm Bombyx mori L. Environment and Ecology, 23S(4): 734-736.

12) Venkatesh, M. and Rayar, S.G. (2005). Rearing performance of new multivoltine $\mathrm{x}$ bivoltine hybrids of silkworm, Bombyx mori L. on two mulberry varieties under Dharwad conditions. Karnataka J. Agric. Sci. University of Agricultural Sciences, Dharwad, India, 18(3): 986-989.

13) Sabhat, A., Malik, M.A., Firdose A., Sofi, A.M. and Mir, M.R. (2011). Nutritional efficiency of selected silkworm breeds of Bombyx mori L. reared on different varieties of mulberry under temperate climate of Kashmir. African J. Agr. Res. 6(1): 120126.

14) Kumar, J.S. and Kumar, N.S. (2011). Production Efficiency of Cocoon Shell of Silkworm, Bombyx mori L. (Bombycidae: Lepidoptera), as an Index for Evaluating the Nutritive Value of Mulberry, Morus sp. (Moraceae), Varieties. Article ID 807363.

15) Waldbauer, G.P. (1964). The consumption, digestion and utilization of solanaceous and nonsolanaceous plants by larvae of the tobacco hornworm, Protoparea extra (Lepidoptera: Sphinigidae). Entomol. Exp. Appl., 7:252-259.

16) Mahmoud, S.M. (1988). Activation of silk secretion by Silkworms, Philosamia ricini and Bombyx mori L. after applying antibiotics. Ph. D. thesis, Faculty of Agriculture, Cairo University. 